\title{
青海蛇紋岩メランジュ産の藍閃石－緑れん石エクロジャイトの圧力温度シュー ドセクション：予報
}

$P-T$ pseudosection of a glaucophane-epidote eclogite from Omi serpentinite mélange, SW Japan: a preliminary report

\section{辻森＼cjkstart樹** 松本啓作**}

Tatsuki Tsujimori* and

Keisaku Matsumoto **

2005 年 9 月 16 日受付.

2006 年 3 月 10 日受理.

スタンフォード大学地球環境科学教室

Department of Geological and Environmental Sciences, Stanford University, Stanford, California 94305-2115, U.S.A.

+ 現所属：金沢大学ベンチャー・ビジネス・ラ ボラトリー

Present adress; Venture Business Laboratory, Kanazawa University, Kanazawa 920-1192, Japan

** 京都大学大学院理学研究科地質学鉱物学教 室.

Department of Geology and Mineralogy, Graduate School of Science, Kyoto University, Kyoto 606-8502, Japan

Corresponding author; T. Tsujimori, tatsukix@mac.com
Abstract

Glaucophane-epidote eclogite occurs in the eclogitic unit of the Omi serpentinite mélange, SW Japan. The eclogite has a peak mineral assemblage of garnet + omphacite + glaucophane + epidote + quartz + rutile \pm phengite. A $P$ - $T$ pseudosection for a bulk composition appropriate to the eclogite has been calculated using the THERMOCALC 2.75 program in the model system $\mathrm{Na}_{2} \mathrm{O}-\mathrm{CaO}-\mathrm{FeO}-\mathrm{MgO}-\mathrm{Al}_{2} \mathrm{O}_{3}-\mathrm{SiO}_{2}-\mathrm{H}_{2} \mathrm{O}$ (NCFMASH) with quartz and water in excess. In the calculated phase diagram, a trivariant field of garnet + omphacite + glaucophane + zoisite occurs within the high-pressure divariant field of garnet + omphacite + glaucophane + hornblende (sensu lato) + zoisite - it is consistent with the previous $P$ - $T$ estimation of peak metamorphism at $T=550-600{ }^{\circ} \mathrm{C}$ and $P>1.8 \mathrm{GPa}$. The $P$-T pseudosection and average- $P$ calculations using THERMOCALC reveal a significant pressure gap between two contrasting high-grade rocks in the eclogitic unit and the non-eclogitic unit. The glaucophane-epidote eclogite may have experienced higher pressure relative to the non-eclogitic paragonite-garnet amphibolite characterized by a trivariant field of garnet + paragonite + hornblende (sensu lato) + zoisite. Considering inferred thermal structure of present-day subduction zones, glaucophane-epidote eclogite may record subduction metamorphism of young and warm slab.

Key words: glaucophane-epidote eclogite, $P-T$ pseudosection, Renge metamorphic belt, Hida Mountains

\section{は じめに}

近年，造岩鉱物の内部整合性をもつ熱力学データベースを 利用した圧力温度 $(P-T)$ シュードセクションのコンピュー 夕計算が, 変成岩の変成履歴の検討に積極的に用いられるよ うになり，これまでに様々な系の $P-T$ シュードセクション が提案されてきた（例えば, Tinkham et al., 2001; Proyer, 2003; Wei and Powell, 2004, 2006; Matsumoto et al., 2005; Stipska and Powell, 2005). シュードセクションの計算は, 全岩化学組成のマスバランスの式と熱力学方程式を組合せて 安定な鉱物組成共生関係やモード組成などを決定する前進モ デリングであり, 変成岩の解析の 1 つの新しい手法である. しかし, 熱力学データベースや計算する鉱物の固溶体モデル が計算結果に直接反映される. そのため, 計算結果を評価す るために, 実際の岩石の組織などに基づく記載岩石学的検証 が必要になる。これまでに, いくつかの $P-T$ シュードセク ションの計算が青色片岩とエクロジャイトを含む玄武岩質の 高圧変成岩に適応され, 成功している（例えば, Carson et al., 1999, 2000; Arnold et al., 2000; Hoschek, 2001, 2004;

(C)The Geological Society of Japan 2006
Rebay and Powell, 2002; Ballevre et al., 2003; Wei et al., 2003). 既存の鉱物固溶体モデルを用いて計算した $P-T$ シュ ードセクションが，どれほど記載岩石学的な観察事実と調和 的であろうか? 著者らは青海蛇紋岩メランジュ産の藍閃石一 緑れん石エクロジャイト（辻森ほか, 2000; Tsujimori, 2002) について, $\mathrm{Na}_{2} \mathrm{O}-\mathrm{CaO}-\mathrm{FeO}-\mathrm{MgO}-\mathrm{Al}_{2} \mathrm{O}_{3}-\mathrm{SiO}_{2}-\mathrm{H}_{2} \mathrm{O}$ 系 (NCFMASH 系）の P-T シュードセクションを Powell et al. （1998）の THERMOCALC プログラムを使つて計算した．そ の結果, 既存の $P-T$ 見積もりに近い条件に, 実際に観察さ れる鉱物組み合わせの安定領域を確認した. 本稿ではその結 果に地質学的な考察を加えて報告する.

\section{青海蛇紋岩メランジュの高変成度変成岩}

飛騨外縁帯の青海蛇紋岩メランジュ（辻森ほか, 2001a 参 照）に, 青色片岩相からエクロジャイト相の結晶片岩（辻森 ほか, 2000; Tsujimori, 2002） と, 緑れん石角閃岩相から角 閃岩相の結晶片岩（杉村ほか, 1996）が蛇紋岩と共に分布す る（例えば, Banno, 1958; 松本, 1980; 中水ほか, 1989; 宮下, 2003; 椚座ほか, 2004; 辻森, 2004; 田沢, 2004; Nozaka, 


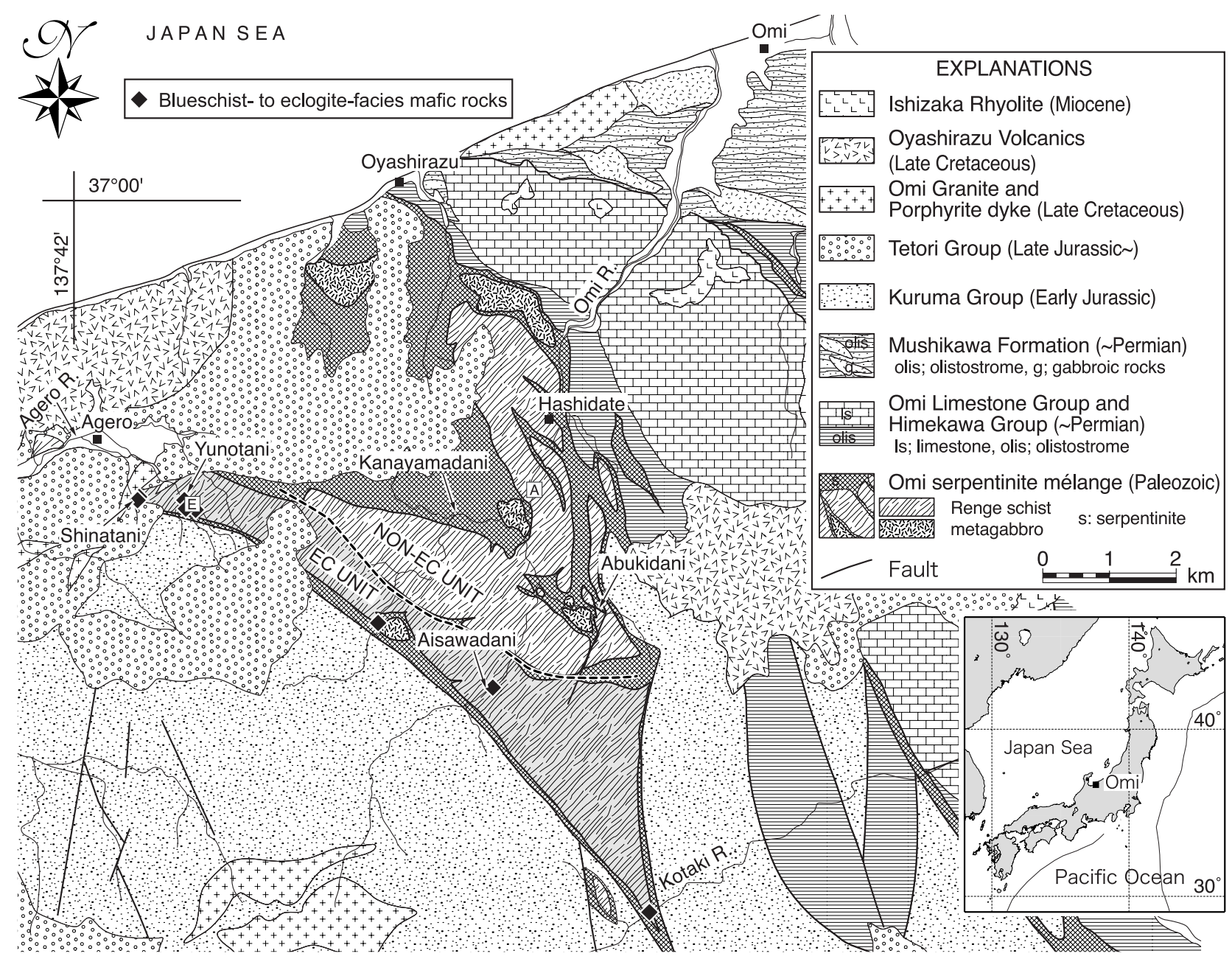

Fig. 1. Geologic map of the Itoigawa-Omi area, showing possible boundary between the eclogitic (EC) unit and the non-eclogitic (non-EC) unit (modified and updated after Tsujimori, 2002). Localities of blueschist- to eclogite-facies mafic high-pressure rocks and paragonite-garnet amphiolite are also shown; E-eclogite; A-paragonite-garnet amphiolite.

2005)。結晶片岩類（蓮華結晶片岩*注积）はそれぞれエクロジ ヤイト相変成岩を含むユニット（EC ユニット）とそれを含 まないユニット（non-EC ユニット）に区分可能である（辻 森ほか, 2001a）（Fig. 1). 両ユニットにはそれぞれ岩石学的 に対照的な高変成度高圧変成岩（藍閃石一緑れん石エクロジ ヤイトとパラゴナイトー緑れん石ーざくろ石角閃岩）が産す る (Fig. 2).

藍閃石一緑れん石エクロジャイト（Fig. 2a）は, 湯ノ谷上 流の EC ユニットのパラゴナイト土鉄藍閃石 + ざくろ石 + 斜 灰れん石＋フェンジャイトの鉱物組み合わせを持つ石英一雲 母質片岩中に互層する苦鉄質層やそのブーダンとして産する

\footnotetext{
*注媲蓮華結晶片岩は, 約 340-280 Ma のフェンジャイト $\mathrm{K}-\mathrm{Ar}$ 及び ${ }^{40} \mathrm{Ar}-{ }^{39} \mathrm{Ar}$ 年代 を示す (例えば, Shibata and Nozawa, 1968; 辻森ほか, 2001b; 椚座ほか, 2004). 同年代のフェンジャイトの K-Ar 系冷却年代を記録した高圧型変成岩が, 九 州中部・北部から中国山地を経て, 飛騨山地の飛騨外縁帯に点在し, それら の放射年代の共通性から, 古生代の広域高圧型変成帯の断片「蓮華帯」とし て認識されている (Nishimura, 1998; Tsujimori and Itaya, 1999). 結晶片岩に 伴う蛇紋岩中のひすい輝石岩の古生代前期のジルコンの U-Pb 年代（約 500-470 Ma）も飛騨山地と中国山地で共通する（椚座ほか, 2002; Tsujimori et al., 2005a).
}

(辻森ほか, 2000; Tsujimori, 2002). 全岩主要・微量元素の 化学組成は海嶺玄武岩に類似する (Tsujimori, 2002). 変成 ピークの鉱物組み合わせは, ‘ざくろ石＋オンファス輝石 + 藍閃石十緑れん石十ルチル十石英”である. また, このユニ ットのエクロジャイトに含まれるざくろ石斑状変晶のコア部 分に, しばしば, エクロジャイト相に先立つ昇温時期の緑れ ん石一青色片岩相の鉱物組み合わせが包有物として保持され ている. また, エクロジャイト相の鉱物組み合わせは, 多か れ少なかれ緑れん石一青色片岩相の重複・再結晶作用を被つ ている. Tsujimori (2002) は石英一雲母質片岩の鉱物組成 共生関係やエクロジャイトのざくろ石一単斜輝石温度計適用 の結果から温度約 $550-600{ }^{\circ} \mathrm{C}$, 圧力> $1.8 \mathrm{GPa}$ の圧力ピー ク時の $P-T$ 条件を見積もつた.

一方，パラゴナイトー緑れん石一ざくろ石角閃岩（Fig. 2b）は, 青海川沿いの non-EC ユニットの黒雲母帯の黒雲 母+ざくろ石十斜長石＋斜灰れん石が安定な石英一雲母質片 岩中に互層する苦鉄質岩層として産する. パラゴナイトはざ くろ石斑状変晶中の包有物及び, まれにマトリクス中に残晶 


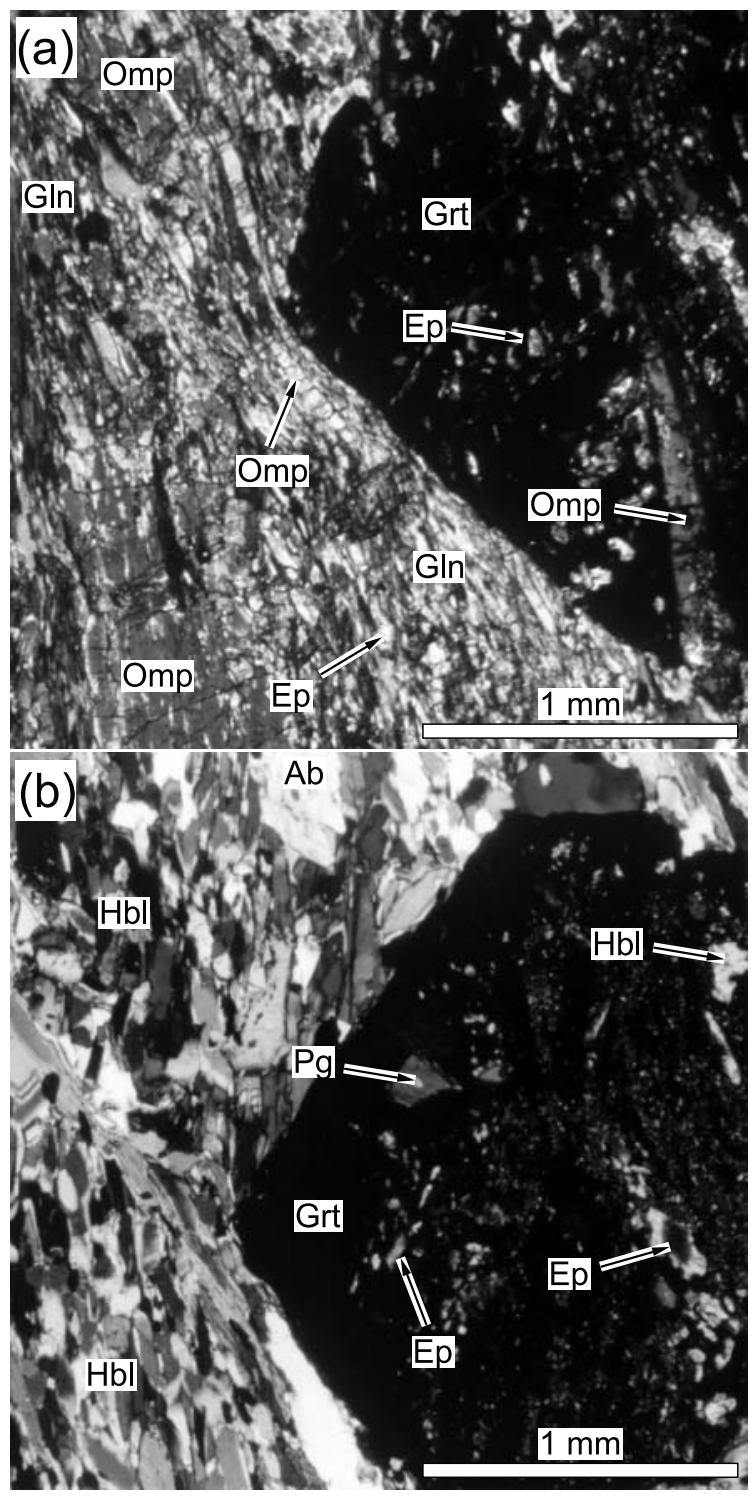

Fig. 2. Photomicrographs of the high-grade mafic metamorphic rocks from the Omi serpentinite mélange. (a) Glaucophane-epidote eclogite from the eclogitic unit [crossed polarized]. (b) Paragonitegarnet amphibolite from the non-eclogitic unit [crossed polarized]

として産する. 昇温組成累帯を持つざくろ石斑状変晶が曹長 石の包有物を含まないこと, マトリクスの曹長石がパラゴナ イトを置換して産することから, 圧力ピークで曹長石は不安 定であり, パラゴナイトは圧力ピーク時に ‘゙くろ石 (alm54-64 $\operatorname{prp}_{5-8}$ grS $\left._{23-31} \mathrm{SpS}_{5-11} ; \mathrm{X}_{\mathrm{Mg}}\left[=\mathrm{Mg} /\left(\mathrm{Mg}+\mathrm{Fe}^{2+}\right)\right]<0.12\right)$ +ホルン ブレンド $\left(\mathrm{Al}_{2} \mathrm{O}_{3}=13-16 \mathrm{wt} \% ;{ }^{[\mathrm{B}]} \mathrm{Na}=0.30-0.65\right.$ a.p.f.u.; $\left.\mathrm{X}_{\mathrm{Mg}}=0.56-0.70\right)+$ 緑れん石十パラゴナイト+ルチル十石 英”の鉱物合わせとして安定であったと考えられる. 同じ鉱 物組み合わせで特徵づけられるパラゴナイトー緑れん石一ざ くろ石角閃岩は飛騨外縁帯の伊勢地域にも産し, Tsujimori et al. (2006a) は伊勢地域のパラゴナイトー緑れん石ーざく ろ石角閃岩について, 鉱物の組成共生関係から温度約 530$570{ }^{\circ} \mathrm{C}$, 圧力 $1.1-1.4 \mathrm{GPa}$ の圧力ピーク時の変成条件を見 積もった.
本稿では特に, 全岩組成が報告されている藍閃石一緑れん 石エクロジャイトについて $P-T$ シュードセクションを検討 した.

\section{$\boldsymbol{P}-\boldsymbol{T}$ シュードセクションの計算}

$P-T$ シュードセクションの計算には, $\mathrm{Na}_{2} \mathrm{O}-\mathrm{CaO}-\mathrm{FeO}-$ $\mathrm{MgO}-\mathrm{Al}_{2} \mathrm{O}_{3}-\mathrm{SiO}_{2}-\mathrm{H}_{2} \mathrm{O}$ 系（NCFMASH 系）を仮定した. 相の 種類として, 検討するエクロジャイトの変成ピークで安定な ざくろ石 (Grt) - $[\mathrm{Mg}, \mathrm{Fe}, \mathrm{Ca}]_{3} \mathrm{Al}_{2} \mathrm{Si}_{3} \mathrm{O}_{8}$, オンファス輝石 $(\mathrm{Omp})-[\mathrm{Ca}, \mathrm{Na}][\mathrm{Mg}, \mathrm{Fe}, \mathrm{Al}] \mathrm{Si}_{2} \mathrm{O}_{6}$, 藍閃石 $(\mathrm{Gln})-[\mathrm{Na}, \mathrm{Ca}]_{2}$ $[\mathrm{Mg}, \mathrm{Fe}]_{3}\left[\mathrm{Mg}, \mathrm{Fe}, \mathrm{Al}_{2} \mathrm{Si}_{8} \mathrm{O}_{22}(\mathrm{OH})_{8}, \quad\right.$ 緑れん石，石英 $(\mathrm{Qtz})-$ $\mathrm{SiO}_{2}$ の他に, 藍閃石が安定な玄武岩質エクロジャイトに一般 に産出し得る鉱物として, 広義のホルンブレンド $(\mathrm{Hbl})-$ $[\square, \mathrm{Na}][\mathrm{Na}, \mathrm{Ca}]_{2}[\mathrm{Mg}, \mathrm{Fe}]_{3}\left[\mathrm{Mg}, \mathrm{Fe}, \mathrm{Al}_{2} \mathrm{Si}_{4}[\mathrm{Si}, \mathrm{Al}]_{4}\right.$ $\mathrm{O}_{22}(\mathrm{OH})_{8}$, ローソン石 $(\mathrm{Lws})-\mathrm{CaAl}_{2}\left[\mathrm{Si}_{2} \mathrm{O}_{7}\right](\mathrm{OH})_{2} \mathrm{H}_{2} \mathrm{O}$, 藍 晶石 $(\mathrm{Ky})-\mathrm{Al}_{2} \mathrm{SiO}_{5}$, パラゴナイト $(\mathrm{Pg})-[\mathrm{Ca}, \mathrm{Na}]$ $\mathrm{Al}_{3} \mathrm{Si}_{3} \mathrm{O}_{10}(\mathrm{OH})_{2}$, 曹長石 $(\mathrm{Ab})-\mathrm{NaAlSi}_{3} \mathrm{O}_{8}$, を選んだ. 低温 のエクロジャイトでは, オンファス輝石に加えて, 普通輝石 質やひすい輝石質の単斜輝石が産することがあるが（例えば, Matsumoto and Hirajima, 2005; Tsujimori et al., 2005b, 2006b), ここでは, オンファス輝石のみ取り扱った. 系成 分として $\mathrm{Fe}_{2} \mathrm{O}_{3}$ を考慮しないので緑れん石は灰れん石 $(\mathrm{ZO})-\mathrm{Ca}_{2} \mathrm{Al}_{2} \mathrm{O}\left[\mathrm{SiO}_{4}\right]\left[\mathrm{Si}_{2} \mathrm{O}_{7}\right](\mathrm{OH})$ とした. ローソン石, 灰 れん石，藍晶石，曹長石，石英は純粋相と仮定した。 また， 流体相として純粋な $\mathrm{H}_{2} \mathrm{O}$ を仮定した. 固溶体鉱物の活動度 モデルは Carson et al. (1999) に従った. P-T プロジェクシ ヨン及び, $P-T$ シュードセクションの計算は, THERMOCALC 2.75 (Holland and Powell, 1998; Powell et al., 1998) プロ グラムを使用した. 同様の計算条件による $P-T$ シュードセ クションの計算は, Tsujimori et al. (2006b) がフランシス カン帯の高変成度ブロックに適応しており, 記載岩石学的な 観察事実と調和的な結果を得ている. THERMOCALC を用い た $P-T$ シュードセクションの計算の詳細は Powell and Holland (2001) やStowell et al. (2005) を参照されたい. ま た， $P-T$ シュードセクションを計算するプログラムとして は, de Capitani and Brown (1987) の THRIAK-DOMINO や, Connolly (1990) のPerple_Xが知られている. 3つの異な るプログラムを用いた $P-T$ シュードセクションの計算結果 の比較を示した例としては, Hoschek (2004) などがある.

\section{1. $\boldsymbol{P}$ - $\boldsymbol{T}$ プロジェクション}

石英と $\mathrm{H}_{2} \mathrm{O}$ を過剰とした NCFMASH 系, 温度 $500-$ $650{ }^{\circ} \mathrm{C}$, 圧力 $0.8-2.5 \mathrm{GPa}$ の範囲の $P-T$ プロジェクション をFig. 3 に示す. NCFMASH 系の類似した相平衡関係は, Carson et al. (1999, 2000) やHoschek (2001) によって報 告されている. しかし, 著者らの計算は, 緑泥石を考慮にい れなかったので, 低温側（約 $550{ }^{\circ} \mathrm{C}$ 以下）で彼らとは違う 結果を得た. 例えば, Carson et al. (1999) は, 我々のP-T プロジェクションにはない不変点 [Omp Gln], [Omp Czo], [Omp Ky］を示した（不変点の表現法は, Zen, 1966 に従つ た)。なお，彼らは灰れん石の代わりに，斜灰れん石 (Czo) で, 緑れん石を取り扱つた. Hoscheck (2001) は, 曹長石 


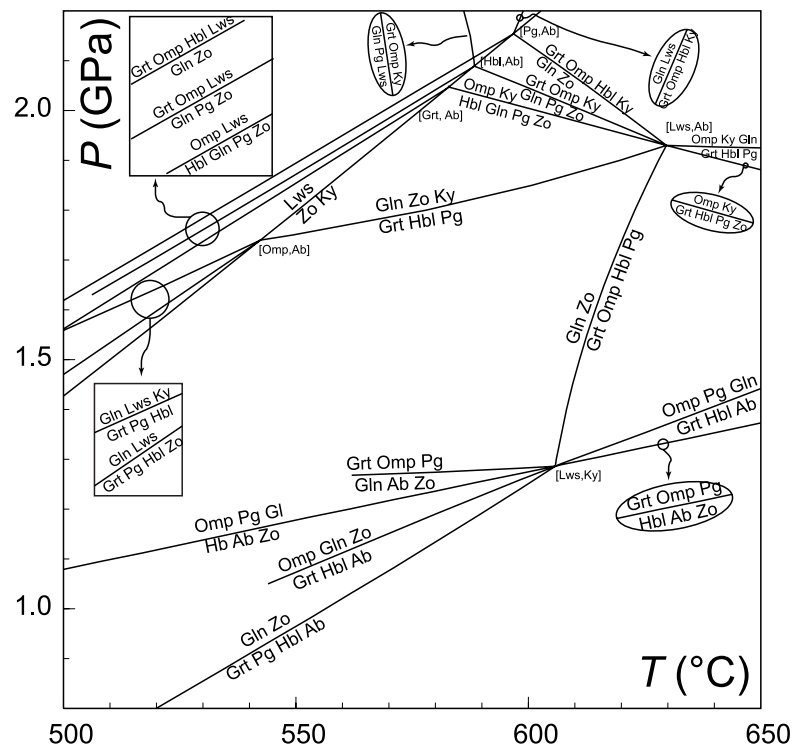

Fig. 3. $P-T$ projection for the full system NCFMASH in projection from quartz and $\mathrm{H}_{2} \mathrm{O}$.

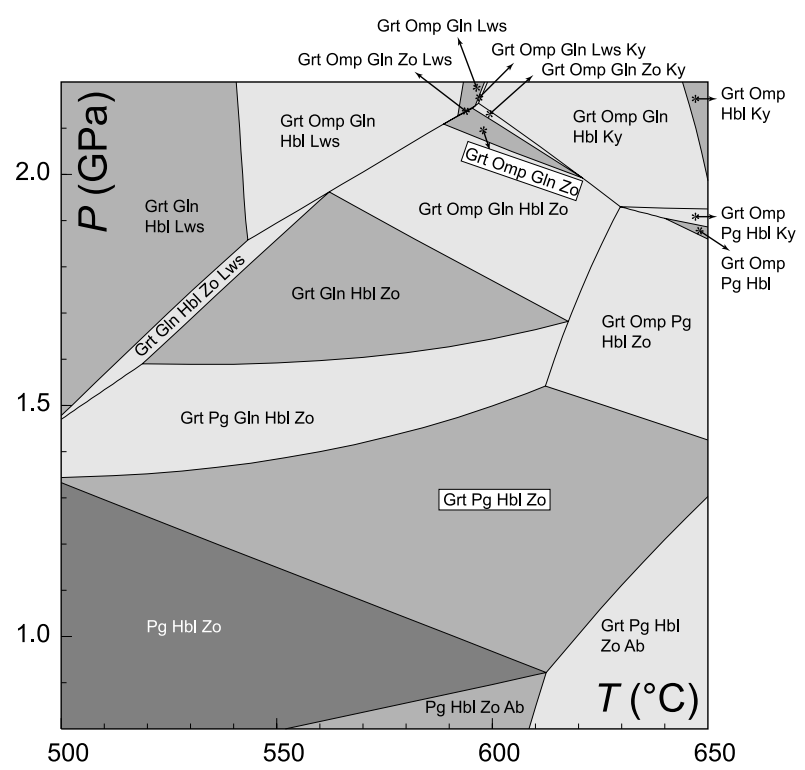

Fig. 4. $P$-T pseudosections in NCFMASH $\left(+\mathrm{Qtz}+\mathrm{H}_{2} \mathrm{O}\right)$ for a bulk rock composition of Omi glaucophane-epidote eclogite (sample "YTEC-2" from Tsujimori, 2002), $\mathrm{Al}_{2} \mathrm{O}_{3}: \mathrm{CaO}: \mathrm{MgO}: \mathrm{FeO}: \mathrm{Na}_{2} \mathrm{O}=$ 22.44: 24.25: 22.02: 24.09: 7.21. Trivariant fields of Grt Omp Gln Zo and Grt Pg Hbl Zo are highlighted. Divariant field: light grey; trivariant field: darker gray; quadrivariant field: darkest gray.

は考慮しておらず，著者らの $P-T$ プロジェクションにはな い不変点 [Omp Pg], [Omp Grt], [Omp Hbl], [Omp Lws] を示した. 著者らの計算は緑泥石の代わりに曹長石を考慮し た結果, 不変点 $[\mathrm{Omp} \mathrm{Ab}]$ を得た. そのような低温での違 いこそあれ，我々の計算した不変点 [Lws $\mathrm{Ab}],[\mathrm{Pg} \mathrm{Ab}]$, [Hbl Ab], [Grt Ab] とそれらから伸びる一変数曲線の束の 関係は, Carson et al. (1999, 2000) やHoschek (2001) の
結果とおおよそ調和的である.

2. $\boldsymbol{P}-\boldsymbol{T}$ シュードセクション

青海の藍閃石一緑れん石エクロジャイトの全岩組成を考慮 した温度 $500-650{ }^{\circ} \mathrm{C}$, 圧力 $0.8-2.5 \mathrm{GPa}$ の範囲の $P-T$ シ ユードセクションを Fig. 4 にしめす。 全岩組成は Tsujimori （2002）が報告した標本 YTEC-2 を用いた。モル\%の比は, $\mathrm{Al}_{2} \mathrm{O}_{3}: \mathrm{CaO}: \mathrm{MgO}: \mathrm{FeO}: \mathrm{Na}_{2} \mathrm{O}=$ 22.44: 24.25: 22.02: 24.09: 7.21 である. 石英と $\mathrm{H}_{2} \mathrm{O}$ を過剰とした NCFMASH 系は実 質, 5 成分系であり, 自由度 0 の不変 (invariant) 点で 7 相 共存, 自由度 1 の一変数 (univariant) 曲線で 6 相共存, 自 由度 2 の二変数（trivariant）領域（一変数曲線で囲まれる $P-T$ 領域）で 5 相共存, 自由度 3 の三変数 (divariant) 領 域（二変数領域に囲まれた $P-T$ 領域）で，4 相共存する. 著 者らが計算した $P-T$ シュードセクションにおいて，ローソ ン石及び藍晶石が不安定な $P-T$ 条件に注目すれば, 二変数 領域 Grt Omp Gln Hbl Zo, Grt Omp Pg Hbl Zo, Grt Pg Gln Hbl Zoは, Carson et al. (1999) がニューカレドニア, パム半島の type II エクロジャイトの全岩組成 $\left(\mathrm{Al}_{2} \mathrm{O}_{3}: \mathrm{CaO}\right.$ : MgO: $\mathrm{FeO}: \mathrm{Na}_{2} \mathrm{O}=20.11$ : 23.63: 26.62: 21.45: 8.19) のP-T シュードセクションの計算で示した二変数領域 Grt Omp Gln Hbl Czo, Grt Omp Pg Hbl Czo, Grt Pg Gln Hbl Czo, に相 当する. 一方, Hoscheck (2001) が東アルプス, ホーエン タウエルンのエクロジャイトの全岩組成 $\left(\mathrm{Al}_{2} \mathrm{O}_{3}: \mathrm{CaO}: \mathrm{MgO}\right.$ : FeO: $\mathrm{Na}_{2} \mathrm{O}=27.7: 27.1:$ 19.8: 13.3: 12.1）について計算し た P-T シュードセクションとは, 二変数領域 Grt Omp Pg Hbl Zo, Grt Pg Gln Hbl Zo が共通するが, そのバルクで安 定な二変数領域 Grt Omp Gln Pg Zo はニューカレドニアの 例と同様に, 青海の藍閃石一緑れん石エクロジャイトの全岩 組成でも得られなかつた.

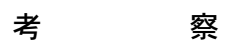

\section{1. 既存の $P-\boldsymbol{T}$ 見積もりとの比較}

計算された $P-T$ シュードセクションが，どれほど記載岩 石学的な観察事実と調和的であろうか? Fig. 4 に示されるよ うに, 青海の藍閃石一緑れん石エクロジャイトの全岩組成に おいて, 二変数領域 Grt Omp Gln Hbl Zo の高圧側にホルン ブレンドの消滅で定義される自由度 3 の三変数領域 Grt Omp Gln Zoが温度約 $600{ }^{\circ} \mathrm{C}$, 圧力約 $2.0 \mathrm{GPa}$ 付近に得ら れた. この領域は青海の藍閃石一緑れん石エクロジャイトに 観察されるざくろ石十オンファス輝石十藍閃石十緑れん石の 鉱物組み合わせに相当し, Tsujimori (2002) が見積もつた 変成条件（温度約 $550-600{ }^{\circ} \mathrm{C}$, 圧力>約 $1.8 \mathrm{GPa}$ ）に近い.

我々の $P-T$ シュードセクションは, 簡単のため $\mathrm{Fe}_{2} \mathrm{O}_{3}$, $\mathrm{TiO}_{2}, \mathrm{MnO}, \mathrm{K}_{2} \mathrm{O}$ は考慮していない. したがって, 厳密には 少量の $\mathrm{Fe}^{3+を}$ を含む緑れん石, 角閃石, オンファス輝石の安 定領域や，Mn を含むざくろ石の安定領域に少なからず影響 を与えることが予想される. 一般に, 青色片岩やエクロジャ イトなどの鉱物共生関系は $\mathrm{Fe}^{3+}$ 効果に敏感である. しか し, $\mathrm{Fe}^{3+を}$ 含む固溶体鉱物の端成分の熱力学的デー夕や固溶 体モデルなどが十分ではないため $\mathrm{Fe}^{3+}$ の効果は NCFMASH 系の $P-T$ シュードセクションにおいて詳細に議論されてい 
ない(例えば, Carson et al., 2000). 緑れん石を斜灰れん石 と見なした CASH 系の反応曲線網では, 緑れん石の $\mathrm{Fe}^{3+}$ の 増加，つまり斜灰れん石の活動度の減少に伴い, 緑れん石を 含む反応曲線が低温高圧側に移動する（Tsujimori， 1999; Tsujimori and Liou, 2004)。 また, 高い酸化状態にある全岩 化学組成では，緑れん石を含む鉱物組み合わせの安定領域が より低温側に移動する (例えば, Enami et al., 2004)。 $\mathrm{Fe}^{3+}$ の効果は緑れん石を含む鉱物共生を低温側に移動させるかも しれない.

一方，青海の藍閃石一緑れん石エクロジャイトのような低 温のエクロジャイトでは, ざくろ石が昇温期の化学組成累帯 を保持し, ざくろ石に多く濃集する元素は，その後の化学平 衡に関与しなくなることが予想される. しかし, Marmo et al. (2002) はニューカレドニアの藍閃石一緑れん石エクロジ ヤイトについて，ざくろ石の分別結晶作用を考慮に入れた $P-T$ シュードセクションを示し, 最大でモード量を $13 \%$ 変 化させても, 昇温から最高変成時期までの鉱物共生の領域に 変化がほとんど無いことを明らかにしている.

\section{2. 地質学的な意味合い}

青海の藍閃石一緑れん石エクロジャイトの全岩組成で計算 した $P-T$ シュードセクション中の三变数領域 Grt Omp Gln Zo の約 0.6-1.0 GPa 低圧側に, 三变数領域 Grt Pg Hbl Zo が得られた (Fig. 4).この鈗物共生は青海のパラゴナイトー 緑れん石一ざくろ石角閃岩の変成ピークの鉱物組み合わせに 相当する. 我々はパラゴナイトー緑れん石一ざくろ石角閃岩 の全岩化学組成を得ていない。しかし, ニューカレドニアの 玄武岩質のエクロジャイトの $P-T$ シュードセクションの計 算においても, 三変数領域 Grt Pg Hbl Czoが, エクロジャ イト相に相当する領域の低圧側に確認されている（Carson et al., 1999). 仮にパラゴナイトー緑れん石一ざくろ石角閃 岩の全岩組成が玄武岩質から大きくはずれるとしても，ホル ンブレンドを含みオンファス輝石を欠く鉱物共生は，藍閃石 とオンファス輝石を含む鉱物共生と比べてより低圧で安定で あろう(例えば，Evans，1990）。実際，THERMOCALC 及び， Ax プログラム (Powell and Holland, 2001) を用いて計算 した温度 $600{ }^{\circ} \mathrm{C}$ における平均圧力は, パラゴナイトー緑れ ん石一ざくろ石角閃岩において約 $1 \mathrm{GPa}$ ，藍閃石一緑れん石 エクロジャイトにおいて約 $2 \mathrm{GPa}$ と, 両者は有意な圧力差 を示す．同地域の 2 つのユニットの高変成度岩には有意な圧 カギャップがあると言える.

\section{3. 藍閃石一緑机ん石エクロジャイトについて}

ざくろ石+オンファス輝石十藍閃石十緑れ九石の鉱物組み 合わせは中国地方の蓮華帯の青色片岩の残晶鉱物組夕合わせ として記載されており, 蓮華帯のエクロジャイト相を特徵づ けている (Tsujimori and Itaya, 1999; Tsujimori and Liou, 2005)。同様の鉱物共生で特徴づけられる藍閃石一緑れん石 エクロジャイトはごのような沈み込み変成作用を代表するで あろうか? 近年, 地球物理学的手法による沈々込久帯断面の 熱モデル計算は, 東北日本やトンガのような古い海洋プレー トが定常的に沈み込む場合，超低地温勾配（約 $5{ }^{\circ} \mathrm{C} / \mathrm{km}$ 以 下）が普通に存在することを予測した（例えば, Kirby et al.,

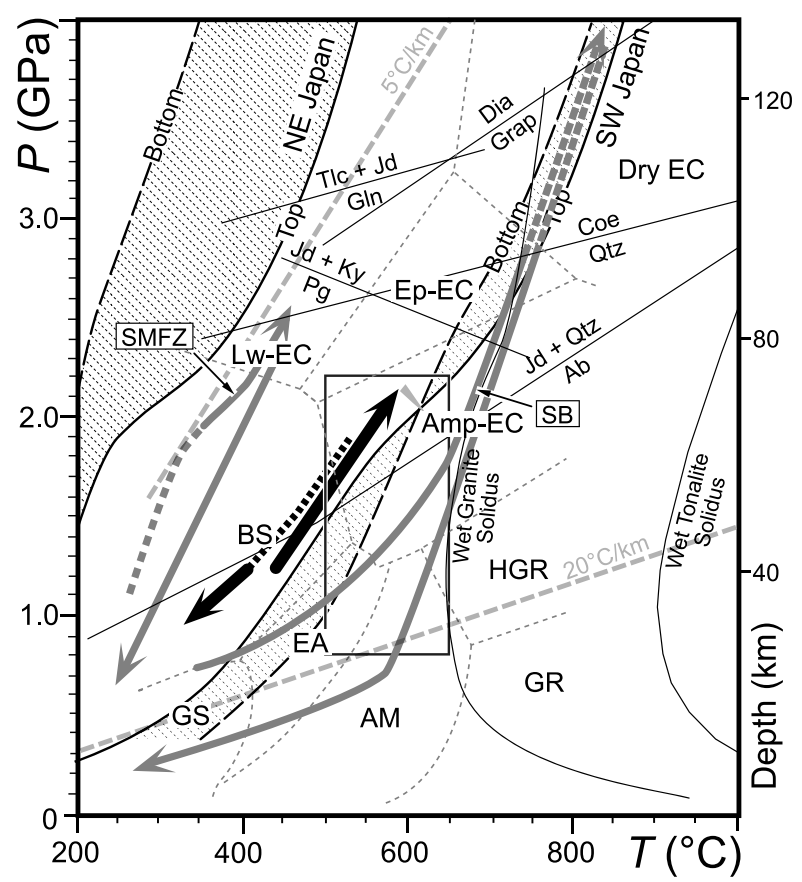

Fig. 5. Qualitative $P-T$ path of Omi glaucophane-epidote eclogite (heavy arrows). The inferred $P-T$ paths of the highest grade rocks of the Sanbagawa metamorphic belt (SB: Ota et al., 2004) and Guatemalan lawsonite eclogite (SMFZ: Tsujimori et al., 2006c) are also shown (gray arrows) for comparison. Hatched areas represent the calculated $P-T$ conditions for oceanic crust beneath present-day NE Japan ('cold') and SW Japan ('warm') subduction zones (Peacock and Wang, 1999); the solid and dashed lines show the top and bottom of oceanic crust. The metamorphic facies and their abbreviations are after Liou et al. (2004). The box represents a $P$ - $T$ space of $P-T$ pseudosections shown in Fig. 4.

1996; Iwamori, 1998; Peacock and Wang, 1999; Hacker et al., 2003a, b; Abers et al., 2006)。これは造山帯の高圧型変 成岩の研究が想定してきた 'forbidden zone’ (禁制帯) の存 在を否定するが, 禁制帯環境での変成再結晶を示唆する超高 圧ざくろ石かんらん岩の報告例（Liou et al., 2000 参照）や， 最近の $\alpha-\mathrm{PbO}_{2}$ 型構造の $\mathrm{TiO}_{2}$ 相を含んだ地殼物質起源の超 高圧変成岩の発見 (Wu et al., 2005), さらに, いくつかの 天然のローソン石エクロジャイトの研究 (Usui et al., 2003; Zack et al., 2004; Tsujimori et al., 2005b, 2006c,d）は超低 地温勾配域の存在を示すものである. 古い海洋プレートの沈 み込みでもスラブ上面温度がかなり高温を示す熱モデル計算 も確かに存在する (van Keken et al., 2002)。しかし，スラ ブ上面の構成岩類を原岩とする天然のローソン石エクロジャ イトの存在は，超低地温勾配域の存在を指示する.

一般に, 藍閃石一緑れん石エクロジャイトは, 約 $8{ }^{\circ} \mathrm{C} / \mathrm{km}$ 程度の地温勾配を記録している(例えば, Hirajima et al., 1988; Miyazaki et al., 1996; Clarke et al., 1997). Fig. 4 が 示すように, 青海の藍閃石一緑れん石エクロジャイトに推定 される昇温時期の $P-T$ 経路は, 超低地温勾配を特徵づける ローソン石エクロジャイトの $P-T$ 経路（例えば, Tsujimori et al., 2006c) とは大きく異なり, むしろ, Peacock and 
Wang (1999）が計算した若いのスラブの沈み込む現在の西 南日本の沈夕込夕帯の $P-T$ 条件に近い。青海の藍閃石一緑 れん石エクロジャイトの記録する $P-T$ 経路は, Ota et al. （2004）が岩石学的解釈によって新しく提案した三波川帯の 変成相系列より $P / T$ 比が高い位置を通ると推定される（Fig， 5)。しかし，ローソン石エクロジャイト相を経験することは ない。このような'暖かい'藍閃石一緑れ九石エクロジャイト は，若いの海洋プレート沈み込みによって形成されるのであ ろう。

\section{謝辞}

本論の執筆にあたり，筆頭著者は日本学術振興会海外特別 研究員研究活動費と米国科学財団研究助成金 (EAR0510325）の一部を，また，第二著者は平成 17 度深田研究 助成の一部をを使用した．河上哲生博士には初稿を校閲して 頂いた．查読者の宮崎一博博士，乾 睦子博士には，多くの 改善意見を頂いた.ここに記して感謝します.

\section{文献}

Abers, G.A., van Keken, P.E., Kneller, E.A., Ferris, A. and Stachnik, J.C., 2006, The thermal structure of subduction zones constrained by seismic imaging: Implications for slab dehydration and wedge flow. Earth Sci. Plat. Lett., 241, 387-397.

Arnold, J., Powell, R. and Sandiford, M, 2000, Amphibolites with staurolite and other aluminous minerals: calculated mineral equilibria in NCFMASH. Jour. Metam. Geology, 18, 23-40.

Ballevre, M., Pitra, P. and Bohn, M., 2003, Lawsonite growth in the epidote blueschists from the Ile de Groix (Armorican Massif, France): a potential geobarometer. Jour. Metam. Geol., 21, 723-735.

Banno, S., 1958, Glaucophane schists and associated rocks in the Omi district, Niigata Prefecture, Japan. Japan. Jour. Geol. Geograph., 29, 29-44.

Carson, C.J., Powell, R. and Clarke, G.L., 1999, Calculated mineral equilibria for eclogites in $\mathrm{CaO}-\mathrm{Na}_{2} \mathrm{O}-\mathrm{FeO}-\mathrm{MgO}-\mathrm{Al}_{2} \mathrm{O}_{3}-\mathrm{SiO}_{2}-\mathrm{H}_{2} \mathrm{O}$ : application to the Pouébo Terrane, Pam Peninsula, New Caledonia. Jour. Metam. Geol., 17, 9-24.

Carson, C.J., Clarke, G.L. and Powell, R., 2000, Hydration of eclogite, Pam Peninsula, New Caledonia. Jour. Metam. Geol., 18, 79-90.

Clarke, G.L., Aitchison, J.C. and Cluzel, D., 1997, Eclogites and blueschists of the Pam Peninsula, NE New Caledonia: a reappraisal. Jour. Petrol., 38, 843-876.

Connolly, J.A.D., 1990, Multivariable phase diagrams: an Algorithm based upon generalized thermodynamics. Am. Jour. Sci., 290, 666-718.

de Capitani, C. and Brown, T.H., 1987, The computation of chemical equilibrium in complex systems containing non-ideal solutions. Geochim. Cosmochim. Acta, 51, 2639-2652

Enami, M., Liou, J.G. and Mattinson, C.G., 2004, Epidote minerals in high P/T metamorphic terranes: Subduction zone and high- to ultrahighpressure metamorphism. In: Liebscher, A. and Franz, G., eds., "Epidotes", Reviews in Mineralogy \& Geochemistry, 347-398.

Evans, B.W., 1990, Phase relations of epidote-blueschists. Lithos, 25, 3-23.

Hacker, B.R., Abers, G.A. and Peacock, S.M., 2003a, Subduction Factory 1. Theoretical mineralogy, densities, seismic wave speeds, and $\mathrm{H}_{2} \mathrm{O}$ contents. Jour. Geophys. Res., 108, 10.1029/2001JB001127.

Hacker, B.R., Peacock, S.M., Abers, G.A. and Holloway, S., 2003b, Subduction Factory 2. Intermediate-depth earthquakes in subducting slabs are linked to metamorphic dehydration reactions: Jour. Geophys. Res., 108, 10.1029/2001JB001129.

Hirajima, T., Banno, S., Hiroi, Y. and Ohta, Y., 1998, Phase petrology of eclogites and related rocks from the Motalafjella high-pressure metamorphic complex in Spitsbergen (Arctic Ocean) and its significance. Lithos, 22, 75-97.

Holland, T.J.B. and Powell, R., 1998, An internally consistent thermody- namic data set for phases of petrological interest. Jour. Metam. Geol., 19, 309-343.

Hoschek, G., 2001, Thermobarometry of metasediments and metabasites from the Eclogite zone of the Hohe Tauern, Eastern Alps, Austria. Lithos, 59, 127-150

Hoschek, G., 2004, Comparison of calculated P-T pseudosections for a kyanite eclogite from the Tauern Window, Eastern Alps, Austria. Eur. Jour. Mineral., 16, 59-72.

Iwamori, $\mathrm{H}$., 1998, Transportation of $\mathrm{H}_{2} \mathrm{O}$ and melting in subduction zones. Earth Planet. Sci. Lett., 160, 65-80

Kirby, S.H., Stein, S., Okal, E.O. and Rubie, D.C., 1996, Metastable mantle phase transformations and deep earthquakes in subducting oceanic lithosphere. Rev. Geophys., 34, 261-306.

棚座圭太郎・中村栄三・宮島 宏・後藤 篤・小林 桂, 2002 , 飛騨外 縁帯糸魚川－青海地域の熱水作用によるヒスイ輝石岩の形成年 代. 岩鉱学会 (徳島大学) 演旨, GP20

椚座圭太郎・後藤 篤・板谷徹丸・横山一己, 2004 , 年代学からみた飛 騨外縁帯の構造発達史: 高圧変成岩類の $\mathrm{K}-\mathrm{Ar}$ 年代と蛇紋岩に接触 変成を与えた花崗岩類の U-Th-Pb EMP 化学年代からの制約. 地 質雑, 110, 591-597.

Liou, J.G., Hacker, B.R. and Zhang, R.Y., 2000, Into the forbidden zone. Science, 287, 1215-1216.

Liou, J.G., Tsujimori, T., Zhang, R.Y., Katayama, I. and Maruyama, S., 2004, Global UHP metamorphism and continental subduction/collision: The Himalayan model. Int Geol Rev., 46, 1-27.

Marmo, B.A., Clarke, C.L. and Powell, R., 2002, Fractionation of bulk rock composition due to porphyroblast growth: effects on eclogite facies mineral equilibria, Pam Peninsula, New Caledonia. Jour. Metam. Geol., 20, 151-165.

松本謙一, 1980, 飛騨外縁带, 青海地域の蛇紋岩メランジ，飛駢外縁帯, no.1, 1-14

Matsumoto, K. and Hirajima, T., 2005, The coexistence of jadeite and omphacite in an eclogite-facies metaquartz diorite from the southern Sesia Zone, Western Alps, Italy. Jour. Mineral. Petrol. Sci., 100, 7084

Matsumoto, K., Banno, S. and Hirajima, T., 2005, Pseudosection analysis for the Sanbagawa pelitic schist and its implication to the thermal structure of high-pressure intermediate type of metamorphism. Proc. Japan Acad. Ser. B, 81, 273-237.

宮下 敦, 2003, 八方尾根のエクロジャイト相変成岩類. 日本地質学会 第 110 年学術大会（静岡大会）講演要旨, 292 .

Miyazaki, K., Zulkarnain, I., Sopaheluwakan, J. and Wakita, K., 1996, Pressure-temperature conditions and retrograde paths of eclogites, garnet-glaucophane rocks and schists from South Sulawesi, Indonesia. Jour. Metam. Geol., 14, 549-563.

中水 勝・岡田昌治・山崎哲夫 ・ 小松正幸, 1989, 飛騨外縁帯, 青海-蓮 華メランジの変成岩類. 地質学論集, no.33, 21-35.

Nishimura, Y., 1998, Geotectonic subdivision and areal extent of the Sangun belt, inner zone of southwest Japan. Jour. Metam. Geol., 16, 129-140.

Nozaka, T., 2005, Metamorphic history of serpentinite mylonites from the Happo ultramafic complex, central Japan. Jour. Metam. Geol., 23, 711-723.

Ota T., Terabayashi M. and Katayama I., 2004, Thermobaric structure and metamorphic evolution of the Iratsu eclogite body in the Sanbagawa belt, central Shikoku, Japan. Lithos, 73, 95-126.

Peacock, S.M. and Wang, K., 1999, Seismic consequences of warm, versus cool subduction metamorphism: examples from Southwest and Northeast Japan. Nature, 286, 937-939.

Powell, R. and Holland, T., 2001, Course Notes for "THERMOCALC Workshop 2001: Calculating Metamorphic Phase Equilibria" (on CD-ROM)

Powell, R., Holland, T.J.B. and Worley, B., 1998, Calculating phase diagrams involving solid solutions via non-linear equations, with examples using THERMOCALC. Jour. Metam. Geol., 16, 577-588,

Proyer, A., 2003, Metamorphism of pelites in NKFMASH - a new petrogenetic grid with implications for the preservation of high-pressure mineral assemblages during exhumation. Jour. Metam. Geol., 21, 493-509 
Rebay, G. and Powell, R., 2002, The formation of eclogite facies metatroctolites and a general petrogenetic grid in $\mathrm{Na} 2 \mathrm{O}-\mathrm{CaO}-\mathrm{FeO}-\mathrm{MgO}-$ $\mathrm{Al}_{2} \mathrm{O}_{3}-\mathrm{SiO}_{2}-\mathrm{H}_{2} \mathrm{O}$ (NCFMASH). Jour. Metam. Geol., 20, 813-826.

Shibata, K. and Nozawa, T., 1968, K-Ar age of Omi schist, Hida mountains, Japan. Bull. Geol. Surv. Japan, 19, 243-246.

杉村和子・中村保夫・相馬恒雄・椚座圭太郎・松本謙一, 1996, 黒雲母 と灰曹長石の生成反応をもとにした変成帯の比較. 地球惑星科学 関連学会合同学会 (大阪) 講演要旨, 506 .

Stipska, P. and Powell, R., 2005, Constraining the P-T path of a MORBtype eclogite using pseudosections, garnet zoning and garnet-clinopyroxene thermometry: an example from the Bohemian Massif. Jour. Metamor. Geol., 23, 725-743.

Stowell, H., Tinkham, D. and Zuluaga, C., 2005, A short course manual for Cordilleran Section of the Geological Society of America (April 2005, San Jose) "Quantitative $P$ - $T$-t Paths from integrated thermodynamic modeling and metamorphic textures" (on CD-ROM).

田沢純一, 2004, 飛騨外縁帯の古生代〜中生代テクトニクスに関する従 来の研究と今後の課題. 地質雑, 110, 565-566.

Tinkham, D.K., Zuluaga, C.A. and Stowell, H.H., 2001, Metapelite phase equilibria modeling in MnNCKFMASH: The effect of variable $\mathrm{Al}_{2} \mathrm{O}_{3}$ and $\mathrm{MgO} /(\mathrm{MgO}+\mathrm{FeO})$ on mineral stability. Geol. Materials Res., 3 , $1-42$.

Tsujimori, T., 1999, Petrogenesis of the Fuko Pass high-pressure metacumulate from the Oeyama peridotite body, southwestern Japan: Evidence for Early Paleozoic subduction metamorphism. Mem. Geol. Soc. Japan, no. 52, 287-302.

Tsujimori, T., 2002, Prograde and retrograde $P-T$ paths of the late Paleozoic glaucophane eclogite from the Renge metamorphic belt, Hida Mountains, southwest Japan. Int. Geol. Rev., 44, 797-818.

辻森 樹, 2004, 組成累帯クロムスピネルからみた青海蛇紋岩メランジ ユを構成する蛇紋岩の起源. 地質雑, 110, 591-597.

过森 樹・石渡 明・坂野昇平, 2000 , 西南日本内帯蓮華変成帯, 青海 町湯ノ谷のエクロジャイト質藍閃石片岩について．地質雑, 106, 353-362.

Tsujimori, T. and Itaya, T., 1999, Blueschist-facies metamorphism during Paleozoic orogeny in southwestern Japan: phengite K-Ar ages of blueschist-facies tectonic blocks in a serpentinite melange beneath Early Paleozoic Oeyama ophiolite. Island Arc, 8, 190-205.

过森 樹・板谷徹丸・兵藤博信, $2001 \mathrm{~b}$, 蓮華変成帯, 湯ノ谷エクロジャ イトの上昇年代: フェンジャイト ${ }^{40} \mathrm{Ar} /{ }^{39} \mathrm{Ar}$ 年代測定の取り組み. 地球惑星科学関連学会合同大会予稿集 (CD-ROM), Gr-P007.

Tsujimori, T. and Liou, J.G., 2004, Metamorphic evolution of kyanite-staurolite-bearing epidote-amphibolite from the Early Paleozoic Oeyama belt, SW Japan. Jour. Metam. Geol., 22, 301-313.

Tsujimori, T. and Liou, J.G., 2005, Eclogite-facies mineral inclusions in clinozoisite from Paleozoic blueschist, central Chugoku Mountains, SW Japan: Evidence of regional eclogite-facies metamorphism. Int. Geol. Rev., 47, 215-232

Tsujimori, T. Liou, J.G. and Coleman, R.G., 2005b, Coexisting retrograde jadeite and omphacite in a jadeite-bearing lawsonite eclogite from the Motagua fault zone, Guatemala.Am. Mineral., 90, 836-842.

Tsujimori, T., Liou, J.G., Ernst, W.G. and Itaya, T., 2006a, Triassic paragonite- and garnet-bearing epidote-amphibolite from the Hida Mountains, Japan. Gondwana Res., 9, 167-175.

Tsujimori, T. Liou, J.G., Wooden, J.L. and Miyamoto, T., 2005a, U-Pb dating of large zircons in low-temperature jadeitite from the Osayama serpentinite melange, SW Japan: Insights into the timing of serpentinization. Int. Geol. Rev., 47, 1047-1058.

Tsujimori, T., Matsumoto, K., Wakabayashi, J. and Liou, J.G., 2006b, Franciscan eclogite revisited: Reevaluation of the P-T evolution of tectonic blocks from Tiburon Peninsula, California. U.S.A. Mineral. Petrol, in press.

辻森 樹 - 宮島 宏・竹之内耕, 2001a, 糸魚川－青海地域の古生代高 圧変成岩. 日本地質学会第 108 年学術大会見学旅行案内書, $157-$ 177.

Tsujimori, T., Sisson, V.B., Liou, J.G., Harlow, G.E. and Sorensen, S.S., 2006c, Petrologic characterization of Guatemalan lawsonite eclogite: Eclogitization of subducted oceanic crust in a cold subduction zone. In: B.R. Hacker et al., eds., "Ultrahigh-Pressure Metamorphism: Deep Continental Subduction": Geol. Soc. Am. Spec. Paper 403, 147-168.

Tsujimori, T., Sisson, V.B., Liou, J.G., Harlow, G.E. and Sorensen, S.S., 2006d. Very-low-temperature record in subduction process: a Review of worldwide lawsonite eclogites. Lithos, in press.

Usui, T., Nakamura, E., Kobayashi, K. and Maruyama, S., 2003, Fate of the subducted Farallon plate inferred from eclogite xenoliths in the Colorado Plateau. Geology, 31, 589-592.

van Keken, P., Kiefer, B. and Peacock, S., 2002, High resolution models of subduction zones: Implications for mineral dehydration reactions and the transport of water into the deep mantle. Geochem. Geophys. Geosys., 3, doi: 10.1029/2001GC000256.

Wei, C., Powell, R. and Zhang, L.F., 2003, Eclogites from the south Tianshan, NW China: petrological characteristic and calculated mineral equilibria in the $\mathrm{Na}_{2} \mathrm{O}-\mathrm{CaO}-\mathrm{FeO}-\mathrm{MgO}-\mathrm{Al}_{2} \mathrm{O}_{3}-\mathrm{SiO}_{2}-\mathrm{H}_{2} \mathrm{O}$ system. Jour. Metam. Geol., 21, 163-179.

Wei, C. and Powell, R., 2004, Calculated phase relations in high-pressure metapelites in the system NKFMASH $\left(\mathrm{Na}_{2} \mathrm{O}-\mathrm{K}_{2} \mathrm{O}-\mathrm{FeO}-\mathrm{MgO}-\mathrm{Al}_{2} \mathrm{O}_{3}-\right.$ $\left.\mathrm{SiO}_{2}-\mathrm{H}_{2} \mathrm{O}\right)$. Jour. Petrol., 45, 183-202.

Wei, C. and Powell, R., 2006, Calculated phase relations in the system NCKFMASH $\left(\mathrm{Na}_{2} \mathrm{O}-\mathrm{CaO}-\mathrm{K}_{2} \mathrm{O}-\mathrm{FeO}-\mathrm{MgO}-\mathrm{Al}_{2} \mathrm{O}_{3}-\mathrm{SiO}_{2}-\mathrm{H}_{2} \mathrm{O}\right)$ for highpressure metapelites. Jour. Petrol., 47, 385-408.

Wu, X.-L., Meng, D.-W. and Hanm Y.-J., 2005, $\alpha$-PbO-type nanophase of $\mathrm{TiO}_{2}$ from coesite-bearing eclogite in the Dabie Mountains, China. Am. Mineral., 90, 1458-1461.

Zack, T., Rivers, T., Brumm, R. and Kronz, A., 2004, Cold subduction of oceanic crust: Implications from a lawsonite eclogite from the Dominican Republic. Eur. Jour. Mineral., 16, 909-916.

Zen, E.A., 1966, Some topological relationships in multisystems of $n+3$ phases. I. General theory, unary and binary systems. Am. Jour. Sci., 264, 401-427. 


\section{(要 旨)}

辻森 樹・松本啓作, 2006, 青海蛇紋岩メランジュ産の藍閃石一緑れん石エクロジャイトの圧 力温度シュードセクション：予報. 地質雑，112，407-414. (Tujimori, T. and Matsumoto, K., 2006, $P$-T pseudosection of a glaucophane-epidote eclogite from Omi serpentinite mélange, SW Japan: a preliminary report. Jour. Geol. Soc. Japan. 112, 407-414.)

青海蛇紋岩メランジュ産の藍閃石一緑れ九石エクロジャイト（Tsujimori, 2002）につい て, $\mathrm{Na}_{2} \mathrm{O}-\mathrm{CaO}-\mathrm{FeO}-\mathrm{MgO}-\mathrm{Al}_{2} \mathrm{O}_{3}-\mathrm{SiO}_{2}-\mathrm{H}_{2} \mathrm{O}$ 系（NCFMASH 系）の圧力温度シュードセクショ ンを THERMOCALC 2.75 プログラムを使って計算した．その結果，既存の圧力温度見積も り(温度二約 $550-600{ }^{\circ} \mathrm{C}$, 圧力>約 $\left.1.8 \mathrm{GPa}\right)$ に近い条件に，実際に観察される鉱物組み合 わせの安定領域が存在することを確認した．現在の沈み込夕帯の推定地温勾配を仮定する 限り, 藍閃石一緑れん石エクロジャイトは若く暖かいスラブの沈み込み変成作用を記録し ているのであろう. 